\title{
Sobre Práticas de Medicalização e "Loucura": Algumas Reflexões (In)disciplinadas
}

Medicalization Practices and "Insanity": (Un)disciplined Reflections Sobre Prácticas de Medicalización y “Locura”: Algunas Reflexiones (In)disciplinadas

\author{
Esmael Alves de Oliveira ${ }^{1}$ \\ Catia Paranhos Martins \\ Universidade Federal da Grande Dourados
}

\begin{abstract}
Resumo
Este artigo traz diálogos e questionamentos produzidos a partir de diferentes encontros e em diferentes momentos da atuação acadêmica dos autores. Para fins de análise, tomamos a experiência da loucura e dos processos de medicalização como um dispositivo de normalização da vida e nos baseamos em duas imagens-cena, uma etnográfica e outra cinematográfica, em face de nossa atuação como docentes nos Cursos de Ciências Sociais e Psicologia da Universidade Federal da Grande Dourados (UFGD). Ao longo de nosso percurso experimental, autores como Foucault, Deleuze e Guattari, pensadores da Reforma Psiquiátrica brasileira, da Subjetividade e do campo da Saúde Coletiva, serão os nossos inspiradores.

Palavras-chave: medicalização, processos de subjetivação, saúde mental
\end{abstract}

\begin{abstract}
This article sparks off questions and exchange of views stemming from different occasions and different moments of the authors' academic career. For the purposes of analysis, we take the experience of madness and medicalization processes as a device for normalizing life and we base ourselves on two images-scenes, one ethnographic and the other cinematographic, in view of our performance as professors in the Social Sciences and Psychology Courses at the Federal University of Grande Dourados (UFGD). Throughout our experiments, authors such as Foucault, Deleuze and Guattari, thinkers of Brazilian Psychiatric Reform, Subjectivity and Public Health, will be our inspiration. Keywords: medicalization, processes of subjectivation, mental health
\end{abstract}

\section{Resumen}

Este artículo trae diálogos y cuestionamientos producidos a partir de diferentes encuentros y en diferentes momentos de la actuación académica de los autores. Para fines de análisis, tomaremos la experiencia de la locura y de los procesos de medicalización como un dispositivo de normalización de la vida y nos basamos en dos imágenes-escena, una etnográfica y otra cinematográfica, decurrentes de nuestra actuación como docentes en los Cursos de Ciencias Sociales y de Psicología de la Universidad Federal de Grande Dourados (UFGD). A lo largo de nuestra trayectoria experimental, autores como Foucault, Deleuze y Guattari, pensadores de la Reforma Psiquiátrica brasileña, de la Subjetividad y del campo de la Salud Colectiva, serán nuestros inspiradores.

Palabras clave: medicalización, procesos de subjetivación, salud mental

\section{Introdução}

Este artigo traz diálogos e questionamentos produzidos a partir de diferentes encontros e em distintos momentos da atuação acadêmica dos autores. Para fins de análise, tomamos a experiência da loucura e dos processos de medicalização como um dispositivo de normalização da vida e, a partir de duas imagens-cena, uma etnográfica e outra cinematográfica, em face de nossa atuação como docentes nos Cursos de Ciências Sociais e Psicologia da Universidade Federal da Grande Dourados (UFGD), problematizamos a loucura enquanto experiência/experimentação - nesse sentido, como um convite para fazer do pensamento um

\footnotetext{
${ }^{1}$ Endereço de contato: Rua Pedro Viana, 160, Parque Alvorada. CEP: 79823-390, Dourados, MS. E-mail: esmael_oliveira@live.com
} 
ato político, e não um sonífero das práticas em saúde (Pelbart, 1991). Trata-se de um exercício experimental, e assim deliberadamente indisciplinado, que almeja desnaturalizar saberes e práticas que circunscrevem, classificam e compreendem a loucura enquanto experiência individual e essencializada, os quais acabam por invisibilizar as estratégias de resistência dos diferentes sujeitos (Andrade \& Maluf, 2016). Ao longo de nosso percurso experimental, autores como Foucault, Deleuze e Guattari, pensadores da Reforma Psiquiátrica brasileira, da Subjetividade e do campo da Saúde Coletiva, serão os nossos inspiradores.

\section{Imagem-Cena I - A DI\#ERENÇA Medicalizada}

Em trabalho de campo realizado por um dos autores ao longo de 2016 em uma comunidade indígena, localizada na região da Grande Dourados, Mato Grosso do Sul, MS², a partir do diálogo com jovens indígenas Kaiowá, a questão da medicalização aparece como um aspecto importante das relações estabelecidas entre os agentes de saúde e essa população. Embora o trabalho tivesse como foco a narrativa dos jovens sobre sua experiência de ser indígena num contexto hegemonicamente não indígena (ponderando que a localização da terra indígena [TI] se dá em um campo de proximidade com o espaço urbano da cidade de Dourados, MS), a utilização de psicotrópicos se apresentou como uma questão proeminente. Durante o trabalho de campo, ocorreu uma situação que consideramos paradigmática - a fala de uma das crianças indígenas durante uma atividade de desenho que realizávamos: "Já tomou o comprimidinho?".

Logo que começamos o trabalho, em um clima bastante descontraído, as crianças e os jovens estavam bem à vontade com nossa presença. Eles brincavam o tempo inteiro e, nesse aspecto, é possível observar a jocosidade como um elemento constantemente presente no processo de interação do grupo. Tal comportamento, em um contexto de relações interétnicas (vale pontuar que a maioria dos professores não é indígena), não está livre de tensionamentos. Eles se dão em diferentes momentos e são de diferentes ordens. No contexto da sala de aula, observa-se que há uma exigência de que as crianças e os jovens indígenas mantenham um comportamento disciplinado, ou seja, uma postura que é compreendida como a adequada aos padrões estabelecidos para o contexto da sala de aula: centramento, seriedade, atenção, dedicação. No que tange a processos de interação mais amplos, há uma série de incompreensões por parte dos professores não indígenas no que diz respeito aos modos de vida dos indígenas e que tem como cerne sua cosmologia. Em uma de nossas visitas ao campo, uma das professoras compartilhou conosco sua dificuldade de trabalhar a temática da conservação da água, pois, segundo ela, na visão dos indígenas a água seria um recurso inesgotável. Diante de um cenário complexo de interações e relacionamentos, a medicalização emerge como um dispositivo que busca mediar as tensões e incompreensões.

Especificamente, com relação à pergunta "Já tomou o comprimidinho?", tal indagação emergiu a partir do seguinte contexto: quando os indígenas eram interpelados pela professora a se "comportarem" e prestarem atenção no que estávamos falando, eles, em tom de "brincadeira", começaram a acusar uns aos outros de não ter tomado o medicamento. Isso

\footnotetext{
${ }^{2}$ Trata-se da Terra Indígena Kaiowá (TI) de Panambizinho, no distrito de Panambi, localizada a aproximadamente $20 \mathrm{~km}$ de Dourados, MS.
} 
não passou despercebido por nós. Naquele mesmo momento, tentamos instigá-los a falar mais e, no entanto, apesar de nossa insistência, não entraram em mais detalhes. Na semana seguinte, durante outra atividade, voltaram a mencionar a tal falta de "tomar o comprimido". Fizemos uma nova tentativa de estimulá-los a falar mais sobre a questão. Afinal, o que era o comprimido? Quem precisava tomar o comprimido? Por que tinham de tomar? Quem orientava tal procedimento? A resposta foi imediata: era preciso tomar o medicamento para se controlar.

Há muitos relatos de medicalização dos indígenas na cidade de Dourados - embora, até o momento, não haja nenhuma pesquisa a esse respeito - e, geralmente, são associados a algumas situações de violência ou a casos de suicídio. Em todos eles, a noção de que os indígenas precisam ser contidos, estão desequilibrados, doentes e/ou loucos é recorrente. Nessas representações, a presença de uma noção de patologização dos sujeitos (individuais e coletivos) que estão à margem, com vidas precarizadas pelo Estado, ao buscarem estratégias de transbordamento das contenções das estruturas estatais que os circundam, faz com que eles sejam inseridos em códigos e relações de assujeitamento. Ao invés de potencializar os múltiplos sentidos dos agitos, dos gritos, do convite à celebração das expressões "subversivas", impera justamente o oposto, ou seja, a tentativa de docilização dos corpos. Diante da dificuldade de compreensão da diferença, opera-se segundo uma lógica que busca docilizar corpos, sujeitos, práticas. O comportamento tido como desviante passa a ser enquadrado segundo uma mecânica de (des)subjetivação. Nessa seara, o limite entre o normal e o patológico é tênue e constantemente negociado e agenciado. Em uma sociedade marcada pela criação de mecanismos sofisticados de governo da vida, o discurso biomédico tem se constituído como um importante aliado (Foucault, 2001). Além disso, os laudos psiquiátricos emergem como a engrenagem por excelência de um saber-poder que tem o corpo como alvo privilegiado.

\section{Imagem-Cena II - A DIғERENÇA (En)Quadrada}

Em um projeto cinematográfico intitulado Loucossão, a psicóloga Rosângela Alfiero, em parceria com o cineasta amazonense Luiz Carlos Martins, buscou construir uma narrativa com alguns usuários do Hospital Psiquiátrico Eduardo Ribeiro de Manaus que tiveram suas trajetórias de vida marcadas pelos processos de institucionalização. O documentário, produzido em 2014, entre outras coisas, problematiza os discursos e as práticas que têm historicamente sustentado a loucura como uma "condição" de marginalidade e exclusão.

Em cena, no documentário, temos múltiplos atores, posicionalidades, situações, lógicas, construções de sentido, reiterações, rejeições, incômodos, subversões, estratégias de existência e reexistência. Loucossão é um projeto de experimentação que põe a loucura em suspensão e o sujeito "louco" em primeiro plano. Dos corredores do hospital psiquiátrico, aos flanares pelas ruas da cidade de Manaus, os diálogos travados, os "papéis-dramas" vividos/interpretados pelos personagens reais da trama, somos conduzidos a uma narrativa dissidente e dissonante: "Sou louco, objeto de seu diagnóstico, de suas fofocas, de sua culpa. Sou louco e não me enxergam. Sou invisível" (Martins \& Alfiero, 2014).

A seguir, transcrevemos um trecho do diálogo entre a psicóloga-personagem e a usuária-personagem. Na cena, temos, no mínimo, dois mundos e a (im)possibilidade de diálogo: 
Psicóloga-personagem: Onde você vê no quadrinho vai aparecer no filme. Direciona a câmera para onde você quer levar.

Usuário-personagem: Não sei, eles que sabem.

Psicóloga-personagem: Eles quem que sabem?

Usuário-personagem: Olha aqui o bichinho.

Psicóloga-personagem: Aí tem um bichinho?

Usuário-personagem: Tem um bichinho de joelho.

Psicóloga-personagem: É? Ele que sabe?

Usuário-personagem: É.

Psicóloga-personagem: Então como é que a gente faz pra perguntar dele.

Usuário-personagem: Bichinho desajoelha.

Psicóloga-personagem: Bichinho se ajoelha?

Usuário-personagem: Bichinho desajoelha.

Psicóloga-personagem: Mas mostra pra mim. Tá vendo ele? Tá vendo ele?

Usuário-personagem: Tô.

Psicóloga-personagem: Mas onde ele tá? Mostra pra mim onde é que ele está.

Usuário-personagem: Tá bem aqui, ó.

Psicóloga-personagem: Aqui? Eu queria entender por que ele é invisível pra mim e visível pra ti.

Usuário-personagem: Tu queria entender?

Psicóloga-personagem: Eu queria entender. A gente olha pra mesma direção e vê coisas diferentes eu e tu, né? [Transcrição de trecho do documentário Loucossão, 2014].

Andrade e Maluf (2016), tomando como marco a Política Nacional de Saúde Mental, apontam que, com relação ao movimento da Reforma Psiquiátrica no Brasil, podemos pensar em avanços e conquistas em termos de desistinsticionalização, mas ao mesmo tempo pouca atenção tem sido dada aos usuários dos serviços de saúde mental enquanto agentes ativos do processo. Assim, Andrade e Maluf, a partir de trabalho de campo realizado junto a usuários dos serviços de saúde mental, questionam a categoria universalizante e homogeneizante de "usuário". Se a experiência relatada em Loucossão fala de um lugar de questionamento das lógicas de sentido entre eu e o outro - "Sou louco, não penso como eles. Não me adequo às suas convenções" -, a etnografia de Andrade e Maluf sinaliza que mesmo esse "eu" é atravessado por múltiplas posicionalidades, construções de sentidos e agenciamentos.

Do mesmo modo que a antropologia da saúde tem chamado a atenção para o fato de que a doença não é uma essência (o doente), mas uma experiência (estar doente) (Langdon, 1994, 2005; Sarti, 2010), o desafio é o de pensarmos que uma possível identidade atrelada ao sujeito adoecido e que aponte para uma condição ontológica (o louco, o doente, o esquizofrênico etc.) acaba por obscurecer a dimensão contextual (portanto social, simbólica, política, econômica) que o enreda. Assim, Andrade e Maluf (2016) nos provocam a pensar que, no contexto da Reforma Psiquiátrica, a noção de usuário pouco dá conta dos múltiplos sentidos que são acionados e agenciados pelos diferentes sujeitos envolvidos nesta complexa trama relacional. Portanto falam de uma condição de irredutibilidade dos fenômenos e experiências humanas à dimensão biopsicológica. A partir da constatação da precariedade das categorias ontologizantes, ponderam as autoras que 
Tal precariedade apareceu com vigor nos dados de campo, o que nos fez pensar tais categorias como variáveis, uma vez que reconhecemos uma circularidade de posições ocupadas pelo mesmo sujeito. Aquele/a que era familiar também poderia ser alguém com diagnóstico, usuário/a do sistema de atenção à saúde; aquele/a que era diagnosticado e usuário poderia ser também familiar e, algumas vezes, aquele/a que era trabaIhador/a poderia ter recebido um diagnóstico como ser também familiar. Várias combinações acabaram aparecendo, o que nos alertava para a intercambialidade de posições (Andrade \& Maluf, 2016, p. 255).

\section{Uma Vida Transbordante ou Esgotada pela Lou-Cura?}

Mas o que ambas as imagens-cenas nos ajudam a pensar com relação à experiência da loucura?

Seja na escola, seja nos corredores do hospital psiquiátrico, linguagens que vão, linguagens que vem. Discursos, equívocos, incompreensões, mal-entendidos, desentendidos, mal-estar, incógnitas. Tentativas de direcionamento do olhar-inquiridor-compreensivo. Frustração diante de um horizonte que transborda na incomensurabilidade dos pontos de vista. Um olhar panóptico que tudo quer ver, acompanhar, inquirir, compreender nos mínimos detalhes as entranhas da inconsciência (Foucault, 2005). Um dispositivo-intransitivo cuja lógica da tradução do outro não permite o vislumbre deste, mas seu distanciamento em uma outridade radical.

Talvez possamos compreender os vários momentos de transformação do Manual Diagnóstico e Estatístico de Transtornos Mentais, o DSM로 , como uma das molas de uma engrenagem que vê a loucura e o louco sob o signo da falta, do distúrbio, da doença, da deficiência, da anormalidade, do perigo (Russo \& Venâncio, 2006). O pathos passa a ser sinônimo de patológico, perdendo-se de vista a dimensão experiencial do sofrimento humano, sua polissemia (Lagndon, 1994; Silveira, 2000; Andrade \& Maluf, 2016).

A lógica hegemônica de construção de sentido, alicerçada pelo logocentrismo, não permite simetria e diálogos. Ouvimos, mas não escutamos; olhamos, mas não enxergamos; temos fome de entendimento, linearidade e racionalização. Precisamos ver para "crer", precisamos ter uma "certeza cirúrgica" sobre o outro, seus desejos, seus "delírios", seus sintomas para poder definir a sua condição de "doente" e, quem sabe assim, encontrar uma solução para seus problemas. Em todo caso, é preciso diagnosticar, enquadrar, patologizar (nos dias atuais, medicalizar!). Uma anátomo-política da loucura que modula, compara, gesta, formata e adoece a vida. De forma concomitante, uma experiência-resistência que escapa, incomoda e amedronta. Por que não dizer que em cena duelam duas concepções contrastivas de sentido de si? Uma que tem na medicalização, no diagnóstico, no DSM e/ou no CID sua razão de ser (a loucura), outra que aponta para a capacidade de ressignificação de si, para a hibridez, para cruzamentos e interseccionalidades de ser e estar no mundo (loucura).

\footnotetext{
${ }^{3}$ O Manual Diagnóstico e Estatístico de Transtornos Mentais é uma formulação da Associação Psiquiátrica Americana e sua primeira edição (DSM I) remete aos anos de 1952, sendo replicado pela Organização Mundial de Saúde na Classificação Internacional de Doenças (CID). Atualmente, após sucessivas revisões e edições (respectivamente DSM II - 1968, DSM III - 1980, DSM III-R - 1987, DSM IV - 1994, DSM IV-TR - 2000), encontra-se na quinta edição (DSM V), publicada em 2013.
} 
O que é a loucura? Quem a define? É possível estabelecer uma tipificação que tenha validade universal? Que seja absoluta? Mas quem é o "louco"? Louco em relação a que ou a quem? É possível pensar a "normalidade" como critério antitético de definição da loucura? Mas quem é o "normal"? São questões que não passam despercebidas quando nos confrontamos com os manuais voltados para o diagnóstico das doenças mentais, como os DSMs (Russo \& Venâncio, 2006).

Conforme João Frayze-Pereira (1984), trata-se de uma questão problemática questionar sobre o que é a loucura. A loucura não apenas foi compreendida de diferentes modos ao longo do tempo e segundo diferentes contextos socioculturais - de compreensões místico-religiosas aos processos bio-psico-fisiológicos - como também esteve predominantemente atrelada a discursos de caráter moralizante, comumente associada a noções como "irracionalidade" e "anormalidade". Sua história, portanto, não pode ser compreendida desvinculada de questões de ordem político-social em que o papel das instituições se mostra proeminente.

Ao analisar os Manuais Diagnósticos e Estatísticos das Doenças Mentais, Dunker (2014, p. 106) destaca que "[...] 52\% dos pesquisadores envolvidos na reformulação que engendrou o DSM V declaram ligações formais e recebimento de proventos por parte da indústria farmacêutica". Deste modo, problematizar a loucura e os saberes e poderes que a circunscrevem implica ampliar o olhar para o crescente interesse com investimentos milionários da indústria farmacêutica em pesquisas sobre os denominados transtornos neurológicos e doenças mentais.

Nesse quadro, não seria a "loucura" e o sujeito "louco" produtos de um dispositivo de saber-poder que, por meio da noção de "normalidade", cria uma tipificação que engendra e sustenta mecanismos de controle e exclusão? Ou seja, não seriam efeitos de poder? (Foucault, 2001).

Esse exercício de problematização não significa negar a experiência de sujeitos com os quais nos encontramos há mais de uma década e que beiram ou estão inundados pela insanidade. Para nós, a colocação de questões é parte de nosso compromisso ético e político na construção de um olhar alinhando com a ética da Atenção Psicossocial (Amarante, 1995) e com a justiça social.

No entanto nos parece que na "sede" de classificação, diagnóstico e normalização da vida, não tem havido espaço para a escuta atenta e despretensiosa de experiências de diferentes modos de ser e estar no mundo e que não correspondem às expectativas socialmente estabelecidas pela racionalidade moderna. Afinal, o que é a normalidade? Quem a define e, mais do que isso, quem a possui?

Como uma dimensão essencial na nossa cultura, Pelbart (1991) considera a loucura como "a estranheza, a ameaça, a alteridade radical. Tudo aquilo que uma civilização enxerga como o seu limite, o seu contrário, o seu outro, o seu além", com potencial de desterritorialização, "de embaralhar os códigos, subverter as regras do jogo e transpor ou deslocar os limites" (Pelbart, 1991, p. 132).

Ao desnaturalizar a loucura como doença mental e lembrarmos que esta colagem é datada, Michel Foucault (2005), em sua História da Loucura, mostra-nos que, enquanto a cidade trancafiava os desarrazoados produzindo a doença mental, o pensamento racional decretava 
a incompatibilidade absoluta entre loucura e razão com a filosofia de Descartes. Sendo assim, é neste momento histórico - aqui e agora - que a desrazão está no louco, mas já ocupou diferentes lugares em outros períodos da história da humanidade.

Foucault (1996) também evidencia como as práticas de controle e de vigilância produziram um saber sobre o humano, que está ordenado em torno da norma, do que é ou não normal. Ao refazer o percurso do nascimento das ciências humanas e do indivíduo, o autor nos mostra que ambos nasceram do esquadrinhamento do corpo. Na sociedade disciplinar, o saber clínico é produzido de modo que o corpo anormal, doente e cheio de sintomas, nada pode além de ser tratado no leito. E a loucura, além de tratada no leito, foi trancafiada a sete chaves.

Loucura, doença mental, esquizofrenia? Psicose? Insanidade? Desrazão? Não haveria outros atravessamentos para além da patologização nosológica desta experiência? Andrade e Maluf (2016) apontam justamente para os limites e as contradições de uma prática que tende a resumir os processos de adoecimento a uma dimensão orgânica, a uma ontologização da doença e do sujeito adoecido. Para as autoras, esse tem sido o viés das abordagens e intervenções presentes nas políticas de saúde mental. Assim, ao pretender-se "objetiva", "neutra", "descritiva", portanto, sintomatológica, acaba por ignorar os processos de subjetivação e as experiências psíquicas e corporais. Em um quadro de experimentação estética, há de se considerar, sobretudo, o valor e a potência das linguagens.

Não é incomum ouvir na cidade de Dourados que os indígenas não falam. São silenciosos, não "encaram" os interlocutores. Há todo um desconhecimento dos processos que envolvem a construção da pessoa entre os Kaiowá. Ao contrário da ausência de fala, conforme vários trabalhos etnográficos revelam (Melià, 1989; Pereira, 2004; Seraguza, 2013), a pessoa Kaiowá se constitui justamente pela palavra. Portanto não falam ou não são escutados? Se falam, tendem a ser considerados loucos, desequilibrados, perigosos. Se não falam, tendem a ser classificados de estranhos, indolentes, selvagens. Em ambas as posições (falantes ou não), o enquadramento é o da norma que busca sua (des)subjetivação. Nesse quadro, os manuais de classificação pouco ajudam a compreender a experiência da diferença, antes tendem a negar, a eclipsar, a normalizar. Busca-se o apagamento, seja dos planos contextuais, seja dos emaranhados das dimensões sociais, políticas e econômicas, entre outros.

Diante de um cenário marcado cada vez mais por processos de medicalização, em uma lógica de consumo-mercadoria (Dantas, 2016), de medicalização social (Tesser, 2006), em que há a objetificação da saúde, do outro e das relações, haveria espaço para um engajamento do saber biomédico na revisão de práticas e saberes que são responsáveis justamente pela manutenção dessas assimetrias? Para além disso, haveria disposição ética para as experiências dissidentes? Como ignorar a relação de saber-poder entre profissional da saúde e paciente, a valorização de um sujeito eficiente e produtivo em detrimento de um sujeito incapaz ou improdutivo, ou mesmo o poder do capital econômico da "indústria da loucura" na produção dos psicofármacos e na manutenção do aparato manicomial? Não estaria a loucura e, consequentemente, o sujeito "louco" condenados a uma eterna abjeção?

Em uma sociedade marcada pelo consumo de medicamentos, engajada na criação e proliferação de diagnósticos e taxonomias psiquiátricas, no estímulo e valorização de um sujeito produtivo, no enaltecimento de uma estética dos corpos jovens e perfeitos, na busca científi- 
ca por encontrar o gene da doença mental, o que destoa, desenquadra, subverte, devaneia, delira, surta e rompe será enquadrado na lógica dos sintomas. Por isso, não é difícil compreendermos a situação dos jovens Kaiowá no espaço da escola indígena.

Em seu trabalho junto a um grupo de mulheres do sul da ilha de Santa Catarina que experimentam no corpo e na vida a "crise dos nervos", Silveira (2000) pondera como o discurso dos médicos diante das narrativas dessas "pacientes" passa pelo viés da desqualificação. Em cena, valores atravessados pelo gênero, mas também por uma noção de adoecimento que passa pelo caminho incontornável do orgânico-fisiológico. Se não há nenhum indício no "organismo", evidenciado pelos exames clínicos, logo conclui-se pelo diagnóstico de "invenção" das pacientes. São "naturalmente" loucas, desequilibradas, dadas a crises "histéricas". Tudo está na "cabeça", é imaginado.

Da mesma forma, a experiência dos jovens indígenas que ousam subverter a ordem do dispositivo escolar por meio das brincadeiras "fora de hora", também explorada pela operação diagnóstica desqualificadora, tende a passar necessariamente pela tentativa de "encontrar na intimidade invisível das sinapses e na especulativa funcionalidade celular a tal realidade objetiva" (Carvalho \& Amarante, 2000, p. 45). O diagnóstico "louco", "desequilibrado" ou "doente" decreta até onde um corpo-sujeito pode ir. O que pode um corpo-louco? (Deleuze, 2002). Para nós, "[...] não se trata apenas de diagnóstico. Os signos remetem a modos de vida, a possibilidades de existência, são sintomas de uma vida transbordante ou esgotada" (Deleuze, 1992, p. 178). Então, qual o valor do diagnóstico?

Seja na experimentação jocosa da medicalização dos jovens Kaiowá, seja na experiência de uma lou-cura flâneur dos usuários do hospital psiquiátrico de Manaus, evidenciada no documentário, experimentamos na forma e no conteúdo as pitadas de uma lou-cura (uma experimentação da vida que subverte a lógica nosológica do saber biomédico e que aponta para novas estéticas de cuidado de si, portanto CURA). Somos convidados a um passeio desarrazoado, seja pelos espaços institucionais (no caso dos jovens indígenas, pela escola) seja pela cidade, e a assim colocar em suspensão o nosso modo de andar na vida. Portanto uma compreensão dessubstancializadora, que se pretenda alternativa a este modelo patologizante, precisa considerar que contextos, sujeitos, patho-logias, sofrimentos e sintomas não estão desvinculados de subjetividades, intersubjetividades e valores (Andrade \& Maluf, 2016). Uma compreensão assim levada a cabo aponta para a existência de estratégias de resistências e reexistências que somente uma lógica despretensiosa de relação com a diferença pode possibilitar. É assim que compreendemos as iniciativas individuais e coletivas de ressignificação das experiências psi: movimento Stop DSM, movimento pela despatologização das identidades sexuais (Stop Trans Pathologization), movimento de despatologização ASPIE (Aspie for Freedom), a luta antimanicomial, os movimentos pela legalização das drogas etc. Além disso, é importante não perder de vista que o campo biomédico e os saberes psi não se constituem como campos homogêneos, mas são nuançados por disputas e assimetrias que tendem a tornar a busca por legitimidade se não fragmentada, ao menos instável, pois é constantemente performatizada em suas diferentes "versões" sobre o corpo e os processos de adoecimento (Mol, 2008).

Neste exercício ontológico-político (Mol, 2008), as instabilidades são muitas e férteis no processo de criação de estratégias para inventarmos outros olhares e práticas para as vicissi- 
tudes do viver. Por isso perguntamos: como usar os conceitos e nosso saber como ferramentas para produzir novos modos de pensar, sentir e viver? Como usá-los como potência, e não como escudo que nos protege da vida e do outro?

Retomamos Deleuze (1988), que questiona ". . . se o poder é constituído de verdade, como conceber um 'poder da verdade' que não seja mais verdade de poder, uma verdade decorrente das linhas transversais de resistências e não mais das linhas integrais de poder? 'Como ultrapassa a linha'?" (p. 101).

\section{Considerações Finais: Pensar o Presente}

Há pouco encerramos o fatídico ano de 2017. Incertezas marcam o Sistema Único de Saúde (SUS) e a luta pela saúde como dimensão de cidadania, bem como inúmeras outras dimensões da vida coletiva. A redução de recursos financeiros com aprovação do Projeto de Emenda Constitucional no 55 fatalmente trará consequências ao projeto da Reforma Psiquiátrica. Sintetizamos este momento com duas perspectivas dissonantes: por um lado, há discursos pelo fortalecimento à Rede de Atenção Psicossocial (RAPS) e, de forma concomitante, temos o enfraquecimento das ações de redução de danos e a autorização para o uso da violência do Estado.

Embora passível de inúmeras críticas, nas últimas décadas o cenário nacional produziu os serviços substitutivos, centros de convivência, leitos de curta permanência em hospital geral, fomento às ações de saúde mental na atenção básica, experiências de geração de renda, residências terapêuticas, entre outras incontáveis iniciativas pela cidadania e dignidade de sujeitos historicamente à margem.

Há três décadas, no ano de 1987, em Bauru, São Paulo, SP, ocorria o Congresso de Trabalhadores de Serviços de Saúde Mental, importante marco do Movimento da Luta Antimanicomial que ganhou força adotando o lema "Por uma sociedade sem manicômios". Os trabalhadores passaram a se recusar radicalmente a continuar a repetição do mesmo papel, ousaram sonhar em não serem os "carcereiros da loucura" (Yasui, 2010). É do cotidiano das instituições psiquiátricas que nasce um movimento denunciador da violência sofrida pelos doentes mentais e que faz a crítica à indústria da loucura, sendo denominado como Reforma Psiquiátrica Brasileira.

Amarante sintetiza este movimento como

. . u um processo histórico de formulação crítica e prática, que tem como objetivos e estratégias o questionamento e elaboração de propostas de transformação do modelo clássico e do paradigma da psiquiatria. . . . uma crítica estrutural ao saber e às instituições psiquiátricas clássicas, dentro de toda a movimentação político-social que caracteriza a conjuntura de redemocratização (Amarante, 1995, p. 87).

A trajetória da Reforma Psiquiátrica Brasileira ganhou força, atores, legislação, pontos de atenção, disputa de espaço na academia. O sonho ainda atual é de mudanças no cenário da Atenção à Saúde Mental, mas, principalmente, de radicalizar os questionamentos sobre as relações e as práticas de estigma e exclusão que marcam as pessoas que vivem e convivem com a loucura, para assim produzirmos novas possibilidades de vida.

Fazemos mais uma provocação a partir de Pelbart (1991): 
... sim, fim do manicômio, mas igualmente fim do manicômio mental, isto é, um direito à desrazão. . . . mas não confiná-la àquele cantinho privado e secreto de nosso psiquismo chamado 'nossas fantasias', onde ela costuma dormitar inofensiva. O direito à desrazão significa poder pensar loucamente, significa poder levar o delírio à praça pública, significa fazer do acaso um campo de invenção efetiva, significa liberar a subjetividade das amarras da verdade, chame-se ela identidade ou estrutura, significa devolver um direito de cidadania pública ao invisível, ao indizível e até mesmo, por que não, ao impensável (p. 137).

O convite é para desocuparmos o lugar de quem tudo pode: poder de curar, de saber mais do outro que ele mesmo, poder de entender a loucura, de ter respostas prontas; e se permitir experimentar o lugar de estar junto no surto, na produção de sentido, no passeio, na festa, na dor. Assim, a Clínica na (da) Lou-cura é o lugar para experimentar o não saber, que não pode ser preenchido pelo conhecimento racional, por estudos e cursos.

Deleuze e Guattari (1996) colocam que a tarefa é ". . . abrir o corpo a conexões que supõem todo um agenciamento, circuitos, conjunções, superposições e limiares, passagem e distribuição de intensidades. . . . [Utilizar] a consciência do sujeito para fazer dela um meio de exploração" (p. 22).

Não se trata de uma falta, de uma carência, já que “. . . o conhecimento dá à vida leis que a separam do que ela pode, que a poupam de agir e proíbem-na de agir, mantendo-a no quadro estrito das reações cientificamente observáveis" (Deleuze, 1976, p. 82).

Experimentar o não saber é uma brecha, uma fenda, uma fissura para que o clínico aconteça. Sendo assim, é preciso deixar a onipotência de lado e não acreditar que se sabe o momento exato da crise, do surto, de ganhar ou perder um cliente, um beijo ou um "tapa" e, num movimento onipotente, ignorar os não ditos e todo invisível que compõe qualquer relação, que a ciência e a nossa razão não conseguem compreender. Neste encontro, é possível abrir passagem para as intensidades.

A lou-cura nos diz que não é passível de ser aprisionada na nossa limitada racionalidade. É possível ser vivida. Neste experimento, os limites são da ética da vida. O que pode este corpo? O que nós, pesquisadores, militantes, terapeutas e usuários podemos juntos?

Ao prestarmos atenção nos sentidos, sentimentos, vivências, experiências e afetos, saltamos para outro patamar; é dar ênfase aos momentos em que tudo acontece e não conseguimos dizer o que houve. As palavras faltam. É nesta hora que precisamos inventá-las; inventar o nome próprio deste acontecimento. É nesse movimento de criação de palavras, de perguntas e de modos de exercer as práticas clínicas que abrimos fissuras nas cristalizações em nós e no outro.

O convite que a lou-cura ou que os "lou-cos" nos fazem se inscreve em outra lógica, numa língua estrangeira, que não é possível ser decifrada, descoberta, traduzida. Não há nada embaixo do pano: há em cima, na superfície, onde a vida acontece. É na relação que as experimentações são possíveis, que os sentidos são inventados, que vemos os efeitos produzidos e que o futuro pode (re)significar o passado, e não o contrário. Este é o convite que a construção de um outro olhar - com os loucos e com os nem tão loucos assim - nos faz.

Nesta invenção, Guattari (1990) nos faz um alerta: “. . . para a construção de estratégias transformadoras de sentido e ação é preciso despir-se dos jalecos e aventais brancos, a co- 
meçar por aqueles invisíveis que [o povo psi] carrega na cabeça, em sua linguagem e em suas maneiras de ser" (p. 22).

Disponibilizar-se aos encontros e sair das garantias dadas pela instituição, saberes e lugares que ocupamos - segurança e clausura - produz novas formas de existir: linhas de fuga aos modos de subjetivação capitalísticos (Deleuze, 1997). Assim, "ultrapassamos a lenda da certeza e passamos a habitar a existência, como uma experiência possível" (Muylaert, 2000 , p. 144). Em outras palavras, o desafio é a construção de outras imagens-dispositivos que abram possibilidades para uma nova ontologia política (Mol, 2008), em que a experiência da loucura, até então compreendida enquanto lugar do interdito, da abjeção, do perigo, ceda lugar a uma estética da existência - e assim, quem sabe, torne-se efetivamente IOUCURA.

Desta forma, pensamos que a experiência dos jovens indígenas em Dourados e dos pacientes do hospital psiquiátrico de Manaus, antes de evocarem uma condição de vitimização ou de fatalismo, falam de um lugar de resistência, pensado em uma dimensão micro, mas nem por isso menos potente. Nesse sentido, toda tendência a encarar a experiência desses sujeitos como marcada única e exclusivamente pelo viés da precarização permanece insensível, portanto, cega às inúmeras estratégias de enfrentamento.

Ao pensarmos no fenômeno da medicalização de jovens indígenas em Mato Grosso do Sul ou nas mobilizações pelos pacientes dos serviços de saúde mental, não podemos perder de vista, para além dos limites e contradições do sistema, que de fato existem as potencialidades e resistências dos sujeitos e grupos. Se, como aponta Foucault (1995),

O poder só se exerce sobre 'sujeitos livres', enquanto 'livres' - entendendo-se por isso sujeitos individuais ou coletivos que têm diante de si um campo de possibilidade onde diversas reações e diversos modos de comportamento podem acontecer. Não há relação de poder onde as determinações estão saturadas mas apenas quando ele pode se deslocar e, no limite, escapar (p. 244).

Levá-los a sério implica encararmos o fato de que, apesar da vida precarizada (marcada pelos processos de medicalização, pelas práticas de institucionalização etc.), não há espaço para vitimização. Pelo contrário, os sujeitos existem, resistem e reexistem. Deste modo, se, por um lado, as políticas oficiais buscam a reiteração de uma vontade de saber instrumentalizante e substancializadora, por outro, deparamo-nos, a partir destas experiências fronteiriças, com uma potência do viver (cuidado de si). Tudo isso fala de um lugar de experimentação, afetação, vida que pulsa, de uma política e poética da vida, portanto, de uma potente e subversiva lou-CURA.

\section{Referências}

Amarante, P. (Coord.). (1995). Loucos pela vida: A trajetória da reforma psiquiátrica no Brasil. Rio de Janeiro: Editora Fiocruz.

Andrade, A. P. M., \& Maluf, S. W. (2016). Sujeitos e (m) experiências: Estratégias micropolíticas no contexto da reforma psiquiátrica no Brasil. Physis Revista de Saúde Coletiva, 26(1), 251-270. 
Carvalho, A., \& Amarante, P. (2000). Forças, diferença e loucura: Pensando para além do princípio da clínica. In P. Amarante (Org.), Ensaios: Subjetividade, saúde mental, sociedade [on-line]. Rio de Janeiro: Editora Fiocruz.

Dantas, J. B. (2016). O consumo de saúde e felicidade: Uma discussão sobre o fenômeno da medicalização no contemporâneo. In C. G. de Mario (Org.), A contribuição das ciências sociais ao campo da saúde. Jundiaí, SP: Paco Editorial.

Deleuze, G. (1976). Nietzsche e Filosofia. Rio de Janeiro: Ed. Rio.

Deleuze, G. (1988). Foucault. São Paulo: Brasiliense.

Deleuze, G. (1992). Conversações. São Paulo: Ed. 34.

Deleuze, G. (1997). Crítica e clínica. São Paulo: Ed. 34.

Deleuze, G. (2002). Espinosa: Filosofia prática. São Paulo: Escuta.

Deleuze, G., \& Guattari, F. (1996). Mil Platôs - Capitalismo e esquizofrenia (Vol. 3). Rio de Janeiro: Ed. 34.

Dunker, C. I. L. (2014). Questões entre a psicanálise e o DSM. Jornal de Psicanálise, 47(87), 79-107.

Foucault, M. (1995). O sujeito e o poder. In P. Rabinow, \& H. Dreyfus, Michel Foucault: Uma trajetória filosófica para além do estruturalismo. Rio de Janeiro: Forense Universitária.

Foucault, M. (1996). A verdade e as formas jurídicas. Rio de Janeiro: Nau.

Foucault, M. (2001). Os anormais. São Paulo: Martins Fontes.

Foucault, M. (2005). História da loucura: Na Idade Clássica. São Paulo: Perspectiva.

Frayze-Pereira, J. (1984). O que é loucura. 3a ed. São Paulo: Brasiliense.

Guattari, F. (1990). As três ecologias. Campinas, SP: Papirus.

Langdon, E. J. (1994). Representações de doença e itinerário terapêutico dos Siona da Amazônia colombiana. In R. V. Santos, \& C. E. A. Coimbra Jr. (Orgs.), Saúde e povos indígenas. Rio de Janeiro: Editora Fiocruz.

Langdon, E. J. (2005). A doença como experiência: A construção da doença e seu desafio para a prática médica. In R. G. Baruzzi, \& C. Junqueira (Orgs.), Parque Indígena do Xingu: Saúde, cultura e história. São Paulo: Terra Virgem.

Martins, L. C., \& Alfiero, R. (Diretores). (2014). Loucossão [Documentário]. Manaus, AM: ProArte/Secretaria de Estado de Cultura. 23 min. Português, Color, Formato: Digital.

Melià, B. (1989). A experiência religiosa guarani. In M. Marzal et al. O rosto índio de Deus. São Paulo: Vozes.

Mol, A. M. (2008). Política ontológica: Algumas ideias e várias perguntas. In J. A. Nunes, \& R. Roque (Eds.), Objectos impuros: Experiências em estudos sociais da ciência. Porto, Portugal: Edições Afrontamento.

Muylaert, M. (2000). Intermezzo: Mestiçagem nos encontros clínicos (Tese de Doutorado em Psicologia Clínica, Pontifícia Universidade Católica de São Paulo, São Paulo).

Pelbart, P. P. (1991). Manicômio mental - A outra face da clausura. In A. Lancetti (Org.), SaúdeLoucura 2. São Paulo: Hucitec.

Pereira, L. M. (2004). Imagens Kaiowá do sistema social e seu entorno (Tese de Doutorado em Antropologia Social, Universidade de São Paulo). 
Russo, J., \& Venâncio, A. T. A. (2006). Classificando as pessoas e suas perturbações: A "revolução terminológica" do DSM III. Revista Latinoamericana de Psicopatologia Fundamental, 9(3), 460-483.

Sarti, C. (2010). Corpo e doença no trânsito de saberes. RBCS, 25(74), 77-91.

Seraguza, L. (2013). Cosmos, corpos e mulheres kaiowá e guarani de anã à kuña (Dissertação de Mestrado em Antropologia Sociocultural, Universidade Federal da Grande Dourados, Dourados, MS).

Silveira, M. L. (2000). O nervo cala, o nervo fala: A linguagem da doença. Rio de Janeiro: Editora Fiocruz.

Tesser, C. D. (2006). Medicalização social (I): O excessivo sucesso do epistemicídio moderno na saúde. Interface - Comunicação, Saúde, Educação, 10(19), 61-76.

Yasui, S. (2010). Rupturas e encontros: Desafios da reforma psiquiátrica brasileira. Rio de Janeiro: Editora Fiocruz.

Recebido: 17/05/2018

Última revisão: 10/09/2018

Aceite final: 18/09/2018

\section{Sobre os autores:}

Esmael Alves de Oliveira - Doutor em Antropologia Social pela Universidade Federal de Santa Catarina (UFSC), com estágio doutoral na Universidade Eduardo Mondlane (UEM/Moçambique). Mestre em Antropologia Social, especialista em Antropologia e graduado em Licenciatura Plena em Filosofia pela Universidade Federal do Amazonas (UFAM). Professor adjunto do curso de Ciências Sociais do Programa de Pós-Graduação em Antropologia (PPGAnt), da Faculdade de Ciências Humanas da Universidade Federal da Grande Dourados (FCH/UFGD) e do Programa de Pós-Graduação em Antropologia Social da Universidade Federal de Mato Grosso do Sul (PPGAS/UFMS). E-mail: esmael_oliveira@live.com, ORCID: http://orcid.org/0000-0002-9235-5938

Catia Paranhos Martins - Doutora, mestre e graduada em Psicologia pela Universidade Estadual Paulista Júlio de Mesquita Filho (UNESP/Assis). Especialista em Saúde Mental pela Universidade Estadual de Campinas (UNICAMP) e em Saúde do Trabalhador pela Fundação Oswaldo Cruz (FIOCRUZ). Professora da graduação e pós-graduação em Psicologia e do Programa de Residência Multiprofissional em Saúde da Universidade Federal da Grande Dourados (UFGD). Coordenadora do Laboratório Serviço de Psicologia da UFGD (LabSPA). Preceptora do PET - Saúde GraduaSUS. Temas de estudo e trabalho: Psicologia Social, Saúde Coletiva, Sistema Único de Saúde, HumanizaSUS, Saúde Indígena/Indigenista, Gêneros, Saúde Mental, Loucura, Desejo, Esquizoanálise e Cartografias. E-mail: catiaparanhos@hotmail.com, ORCID: http://orcid.org/0000-0003-4905-5865 
